\title{
Single Nucleotide Polymorphisms in IGFBP-2 Gene and Their Associations with Body Weight Traits on Jinghai Yellow Chicken
}

-Author(s)

Zhao XH',"
Li MY"
Xu SS"
Liu GJ"

Heilongjiang Academy of Agricultural Sciences Postdoctoral Programme

" Animal Husbandry Research Institute, Heilongjiang Academy of Agricultural Sciences, Harbin 150086, China

\section{-Mail Address}

Corresponding author e-mail address Animal Husbandry Research Institute, Heilongjiang Academy of Agricultural Sciences, Harbin, Heilongjiang 150086 , China

Email: yzzxh_007@163.com

\section{- Keywords}

Jinghai Yellow chicken, IGFBP-2 gene, PCRSSCP, Polymorphism, Body weight.

\section{ABSTRACT}

Insulin-like growth factor binding protein-2 (IGFBP-2) regulates a broad spectrum of biological activities involved in growth, development, and differentiation. This study aimed at comparing polymorphisms in intron2 of the IGFBP-2 gene among four chicken breeds and at analyzing the associations between its genotypes and body weight in Jinghai Yellow chicken by using PCR-SSCP technique. For primer P2, three genotypes ( $A A, A B$ and $B B$ ) were observed in the four chicken breeds. Gene sequencing revealed one insertion/deletion (the inserted/ deleted TC after position 552bp) in the intron 2 of IGFBP-2 gene. For primer P5, three genotypes were identified in Jinghai Yellow chickens, and named CC, CD and DD. Gene sequencing revealed two SNPs (C1107G, C1130T) and one inserted/deleted GCCAGGT after 1115bp in the intron 2 of IGFBP-2 gene. The results of the linear model analysis showed that Jinghai Yellow chickens with AA genotype had significantly heavier body weight, at hatch and 12 weeks of age, than those of the $A B$ genotype $(p<0.05)$. The $A$ allele had a positive effect on body weight. We speculate that mutations in intron 2 could be used as genetic markers for body weight in Jinghai Yellow chicken. This study provides valuable information for the protection of genetic resources and for breeding of Jinghai Yellow chicken.

\section{INTRODUCTION}

Traditional genetic selection techniques have resulted in significant improvements in many economically important traits in chickens. Based on pedigree information, traditional selection is laborious and timeconsuming. With the development of genetics and genomics, many new molecular strategies were adopted in chicken genetic selection. The candidate gene approach is a powerful method for finding the QTL responsible for genetic variation of the traits of interest in livestock species (Lamont et al., 1996; Bai et al., 2006). Similar to other economic traits, body weight is under complex genetic control. The elucidation of genes and their networks involved in body weight determination is key in chicken genetics and breeding.

Insulin-like growth factor- I (IGF-I) and IGF- II are growth-promoting polypeptides essential for normal growth and development (Cohick \& Clemmons, 1993). The actions of IGFs are regulated by many factors; IGFBPs regulates growth and development by regulating IGF transport to tissues and IGF bioavailability to IGF receptors at cell membrane level (Silha \& Murphy, 2005).

IGFBP-2 is an important member of IGFBPs family, which has many biological functions. IGFBP-2 is capable of controlling the biological actions of IGFs (Hoeflich et al., 1999) and TGF-B (Rajaram et al., 1997) in vivo via endocrine, autocrine, or paracrine mechanisms and further affects the growth and development of animals. The IGFBP-2 gene has a 
Single Nucleotide Polymorphisms in IGFBP-2 Gene and Their Associations with Body Weight Traits on Jinghai Yellow Chicken

total length of $32 \mathrm{~kb}$ and it is composed by four exons, $2.0 \mathrm{~kb}$ (rat) and $1.6 \mathrm{~kb}$ (human) mRNAs are generated, and the mature protein is approximately $31 \mathrm{kDa}$ in rats and 36 kDa humans (Shimasaki \& Ling, 1991). The chicken IGFBP-2 gene spans to approximately $38 \mathrm{~kb}$, consists of four exons, and presents similar organizaton compared with rats and humans (Schoen et al., 1995).

In the past, the structure and function of the IGFBP-2 gene were analyzed in detail; however, the association of the IGFBP-2 gene with growth traits has not been clarified in chickens yet. The Jinghai Yellow chicken is a Chinese meat-type breed with small size and is characterized by adaptability to poor quality feeds and harsh environments. Bian and Youxi chickens are Chinese breeds raised for both for meat and egg production. Arbor Acre chickens are well known for rapid growth. The objective of this research was to identify SNPs of the IGFBP-2 gene in Jinghai Yellow chickens and three reference chicken populations (Arbor Acre, Youxi, and Bian chickens) using the PCRSSCP technique. Associations between polymorphisms and body weight of Jinghai Yellow chickens were also evaluated in this study. The results presented in this study may provide molecular tools for the selection for body weight in chickens.

\section{MATERIALS AND METHODS}

\section{Chicken populations}

Blood samples were collected from 236 chickens belonging to four chicken populations: Jinghai Yellow chickens (146), Arbor Acre chickens (30), Youxi chickens (30) and Bian chickens (30). Blood samples of female Jinghai Yellow chicken and Arbor Acre chicken were collected at the age of 16 weeks (wk) at the Jiangsu Jinghai Poultry Industry Group Co., Ltd. The body weight of each female Jinghai Yellow chicken was measured at hatching, 4, 8, 12, and 16 weeks of age. These birds hatched on the same day, and were reared in floor pens. Birds had access to feed (commercial corn-soybean diets meeting the requirement of National Research Council's [NRC]) and water ad libitum. Bian chicken's blood samples were collected at the age of $18 \mathrm{wk}$ at the Institute of Animal Husbandry and Veterinary of Shanxi Academy of Agricultural Sciences. Youxi chicken's blood samples were collected at the age of $16 \mathrm{wk}$ at the National Gene Bank for Local Chickens in Poultry Institute, Chinese Academy of Agricultural Sciences.

Genomic DNA was extracted from the whole blood using phenol-chloroform method and stored at $-20^{\circ} \mathrm{C}$. The DNA concentrations were quantified spectrophotometrically.

\section{Primers design and PCR amplification}

Based on chicken IGFBP-2 gene sequences (GenBank accession no. NC_006094), five pairs of primers were designed using the Primer Premier 5.0 software and used to amplify the intron 2 of IGFBP- 2 gene. The detailed information of the primers is presented in Table 1.

PCR was performed in a $20-\mu \mathrm{L}$ mixture containing $1 \mu \mathrm{L}$ chicken genomic DNA $(50 \mathrm{ng} / \mu \mathrm{L}), 1 \mu \mathrm{L}$ of each of forward and reverse primer (10 $\mu \mathrm{mol} / \mathrm{L}), 2 \mu \mathrm{L} 10 \times$ buffer, $2.2 \mu \mathrm{L} \mathrm{Mg}^{2+}(25 \mathrm{mmol} / \mathrm{L}), 1 \cup \mathrm{Taq}$ DNA Polymerase (Sangon Biological Engineering Technology Company, Shanghai, China), $2 \mu \mathrm{L}$ dNTPs ( $2 \mathrm{mmol} / \mathrm{L}$ ), and 11.8 $\mu \mathrm{L}$ sterilized water. The amplification conditions were: initial denaturation at $94^{\circ} \mathrm{C}$ for $6 \mathrm{~min}$, followed by 30 cycles of denaturation at $94^{\circ} \mathrm{C}$ for $30 \mathrm{~s}, 30 \mathrm{~s}$ at annealing temperature $\left(58-62^{\circ} \mathrm{C}\right)$ and extension at $72^{\circ} \mathrm{C}$ for $30 \mathrm{~s}$, and at last $10 \mathrm{~min}$ of at $72^{\circ} \mathrm{C}$. PCR products were verified by electrophoresis on $1 \%$ gel. Gels were stained with Gold View.

\section{Single-strand conformation polymorphism (SSCP) and sequencing}

For SSCP analysis, $2 \mu \mathrm{L}$ of each amplification product was mixed with $7 \mu \mathrm{L}$ denaturing buffer $(98 \%$ formamide, $0.025 \%$ xylene cyanole $\mathrm{FF}, \quad 0.025 \%$ bromophenol blue, $10 \mathrm{mmol} / \mathrm{L}$ EDTA $(\mathrm{pH} \mathrm{8.0})$ and $10 \%$ glycerol), heated for $10 \mathrm{~min}$ at $98{ }^{\circ} \mathrm{C}$ and then cooled on ice for $5 \mathrm{~min}$. Denatured PCR products were subjected to $10 \%$ non-denaturing polyacrylamide gels

Table 1 - Primer sequences for amplification of the IGFBP-2 gene

\begin{tabular}{lll}
\hline Primer name & Upper Primer sequences $\left(5^{\prime} \rightarrow 3^{\prime}\right)$ & Down Primer sequences $\left(5^{\prime} \rightarrow 3^{\prime}\right)$ \\
P1 & F: CACAACCACGAGGACTCAAA & R: GCTTCAGGCCAAAATAAACG \\
P2 & F: GCGAGGAGGCGTTATTTC & R: TAAATCCCTCAGGCCATCC \\
P3 & F:AAGTAACTCCCCAGGGATGG & R: TTTCCATCCCCATGACATCT \\
P4 & F:GGCATGTCATGGGGATGGAAA & R: GGAGATGAGGCCACAAACA \\
P5 & R: TCTTCACGTGGCAAAGAGC \\
\hline
\end{tabular}


Single Nucleotide Polymorphisms in IGFBP-2 Gene and Their Associations with Body Weight Traits on Jinghai Yellow Chicken

(29:1) at $150 \mathrm{~V}$ for 11 to $13 \mathrm{~h}$ at $16^{\circ} \mathrm{C}$. SSCP patterns on the gels were visualized by silver staining.

PCR products of homozygous / heterozygous individuals of different genotypes were purified with DNA Fragment Quick Purification/Recover Kit. The purified PCR products were sequenced in both directions.

\section{Statistical analysis}

The Chi-square test was used to verify the significance of differences in genotypic and allelic frequencies between different breeds and the HardyWeinberg equilibrium. The following linear model (GLM) was established to analyze the genotype effects of IGFBP-2 gene on body weight traits.

$$
\mathrm{y}_{\mathrm{ij}}=\mu+G_{i}+e
$$

Where, $y_{i j}$ represented the body weight traits, $\mu$ was the overall mean, $G_{i}$ was the genotypic effect of IGFBP-2 gene, e was the residual error.

These statistical analyses were carried out using the SPSS 17.0 software.

\section{RESULTS}

\section{Detection of the mutation in IGFBP-2 gene}

Amplicons with expected size were obtained from chicken DNA using different primers. Two (P2 and P5) primers showed polymorphisms among the five pairs of primers. For primer $P 2$, three genotypes $(A A, A B$ and $\mathrm{BB}$ ) were observed in the four chicken breeds (Figure 1).

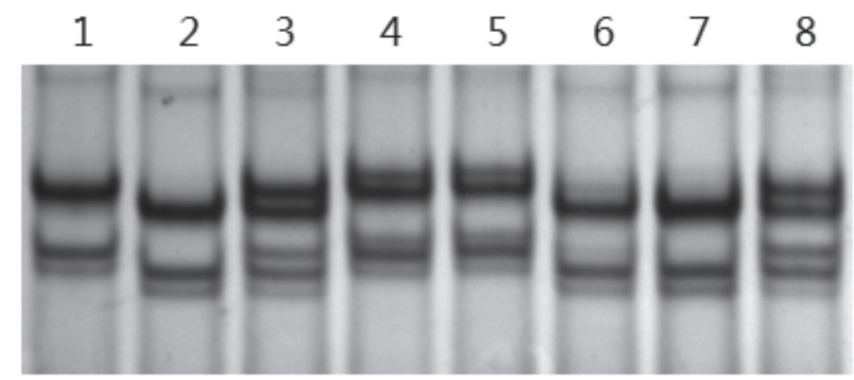

Figure 1 - SSCP analysis of PCR amplification using primers $P 2$ in different chicken breeds 1, 4, 5: BB genotype; 2, 6, 7: AA genotype; 3, 8: AB genotype
Forward and reverse sequencing results revealed that one insertion/deletion (the inserted/deleted TC after position 552bp) in the intron 2 of IGFBP-2 gene. For primer P5, three genotypes were identified in Jinghai Yellow chickens, named CC, CD and DD, respectively (Figure 2).

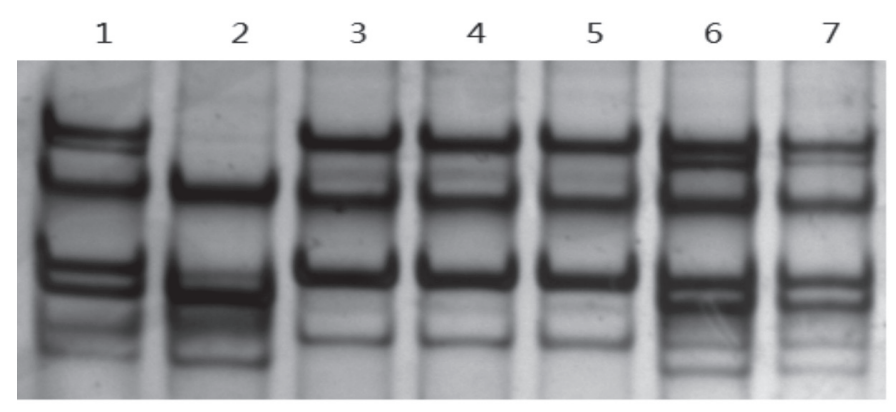

Figure 2 - SSCP analysis of PCR amplification using primers P5 in different chicken breeds 3, 4, 5: CC genotype; 1, 6, 7: CD genotype; 2: DD genotype

The nucleotide sequence obtained from genotype DD was identical to the wild-type CC, except for C1107G, C1130T and one insertion/deletion (the inserted/deleted GCCAGGT after 1115bp) in the intron 2 of IGFBP-2 gene.

\section{Allele variation and genotype distribution of IGFBP-2 gene}

Genotype and allele frequencies of IGFBP-2 gene and P-values for the Hardy-Weinberg equilibrium test were presented in Table 2.

For primer P2, allele A was the dominant allele in the Jinghai Yellow and Bian chickens with 0.68 and 0.62 of frequency, respectively. Allele B was the dominant allele in Arbor Acre and Youxi chickens with 0.40 of frequency. The result of Chi-square test showed that the four chicken breeds were in HardyWeinberg equilibrium ( $p>0.05)$. For primer P5, allele $C$ was the dominant allele in Jinghai Yellow, Arbor Acre, Youxi and Bian chickens with frequencies of 0.86 , $1.00,1.00$, and 1.00 , respectively. The Chi-square test showed that the four chicken breeds were in HardyWeinberg equilibrium ( $p>0.05)$.

Table 2 - Distribution of genotypes and allele frequencies in four chicken breeds

\begin{tabular}{|c|c|c|c|c|c|c|c|c|c|c|c|c|c|}
\hline \multirow{3}{*}{ Breeds } & \multirow{3}{*}{ No. } & \multicolumn{5}{|c|}{ P2 } & \multirow{3}{*}{$\chi^{2}$} & \multicolumn{5}{|c|}{ P5 } & \multirow{3}{*}{$\chi^{2}$} \\
\hline & & \multicolumn{2}{|c|}{$\begin{array}{c}\text { Allele } \\
\text { frequency }\end{array}$} & \multicolumn{3}{|c|}{ Genotype frequency } & & \multicolumn{2}{|c|}{$\begin{array}{c}\text { Allele } \\
\text { frequency }\end{array}$} & \multicolumn{3}{|c|}{ Genotype frequency } & \\
\hline & & $A$ & $B$ & AA & $A B$ & BB & & $C$ & $\mathrm{D}$ & $C C$ & $C D$ & DD & \\
\hline JY & 146 & 0.68 & 0.32 & $0.45(66)$ & $0.45(66)$ & $0.10(14)$ & 0.18 & 0.86 & 0.14 & $0.75(109)$ & $0.23(34)$ & $0.02(3)$ & 0.03 \\
\hline AA & 30 & 0.40 & 0.60 & $0.23(7)$ & $0.33(10)$ & $0.44(13)$ & 2.80 & 1.00 & 0.00 & $1.00(30)$ & $0.00(0)$ & $0.00(0)$ & Null \\
\hline$Y X$ & 30 & 0.40 & 0.60 & $0.17(5)$ & $0.47(14)$ & $0.36(11)$ & 0.02 & 1.00 & 0.00 & $1.00(30)$ & $0.00(0)$ & $0.00(0)$ & Null \\
\hline B & 30 & 0.62 & 0.38 & $0.30(9)$ & $0.63(19)$ & $0.07(2)$ & 3.46 & 1.00 & 0.00 & $1.00(30)$ & $0.00(0)$ & $0.00(0)$ & Null \\
\hline
\end{tabular}

$\mathrm{JY}=$ Jinghai Yellow chicken; $\mathrm{AA}=$ Arbor Acre chicken; $\mathrm{YX}=$ Youxi chicken; $\mathrm{B}=$ Bian chicken; $\mathrm{df}=1, \chi_{0.05(1)}^{2}=3.84, \chi^{2} 0.01(1)=6.64 ;$ Number in the brackets represents number of the genotype in population 


\section{Association of SNP with body weight of Jinghai Yellow chicken}

The associations between IGFBP-2 gene and body weight in Jinghai Yellow chicken are summarized in Table 3.

Table 3 - Least squares means (LSM) and standard deviation (SD) for body weight traits of different genotypes in P2 locus for IGFBP-2 in Jinghai Yellow chicken (1)

\begin{tabular}{llll}
\hline Genotype & $\mathrm{AA}(66)$ & $\mathrm{AB}(66)$ & $\mathrm{BB}(14)$ \\
\hline Hatch weight & $36.07 \pm 0.84^{\mathrm{a}}$ & $34.89 \pm 0.39^{\mathrm{b}}$ & $36.03 \pm 0.39^{\mathrm{ab}}$ \\
\hline 4 week-age-weight & $188.35 \pm 3.22$ & $183.67 \pm 3.22$ & $180.07 \pm 6.99$ \\
\hline week-age-weight & $463.65 \pm 9.53$ & $456.58 \pm 9.53$ & $451.21 \pm 20.69$ \\
12 week-age-weight & $872.06 \pm 14.27^{\mathrm{a}}$ & $832.06 \pm 14.27^{\mathrm{b}}$ & $843.79 \pm 30.98^{\mathrm{ab}}$ \\
16 week-age-weight & $1168.35 \pm 12.24$ & $1138.68 \pm 12.24$ & $1148.21 \pm 26.58$ \\
\hline
\end{tabular}

(1)a, b Means within a line with no common superscript differ significantly $(p<0.05)$

For primer $\mathrm{P} 2$, chickens of the AA genotype had significantly higher body weight, at hatch and 12 weeks of age, than those of the $A B$ genotype $(p<0.05)$. Furthermore, there were no significant differences among different genotypes in body weight at 4,8 , or 16 weeks of age ( $p>0.05)$. For primer P5, there were no significant differences in body weight among genotypes ( $p>0.05$ ) (Table 4).

Table 4 - Least squares means (LSM) and standard deviation (SD) for body weight traits of different genotypes in P5 locus for IGFBP-2 in Jinghai Yellow chicken

\begin{tabular}{llll}
\hline Genotype & $\mathrm{CC}(109)$ & $\mathrm{CD}(34)$ & $\mathrm{DD}(3)$ \\
Hatch weight & $35.33 \pm 0.30$ & $35.85 \pm 0.54$ & $38.67 \pm 1.82$ \\
4 week-age-weight & $185.99 \pm 2.52$ & $183.91 \pm 4.51$ & $182.67 \pm 15.18$ \\
8 week-age-weight & $459.90 \pm 7.42$ & $458.56 \pm 13.29$ & $444.00 \pm 44.74$ \\
12 week-age-weight & $848.98 \pm 11.25$ & $859.82 \pm 20.14$ & $837.33 \pm 67.80$ \\
16 week-age-weight & $1151.90 \pm 9.50$ & $1147.00 \pm 17.01$ & $1261.33 \pm 57.27$ \\
\hline
\end{tabular}

\section{DISCUSSION}

Sequence variation of IGFBP-2 gene in animals was previously reported. Wang et al. (2008), using the PCR-SSCP technique, found three SNP (C502T, A603G, and T1218G) in the IGFBP-2 gene in pigs. Leng et al. (2009) detected one SNP (C1996A) in the $3^{\prime}$-flanking region of the IGFBP-2 gene of the Northeast Agricultural University $F_{2}$ resource population chicken. Based on PCR-RFLP and PCR-SSCP methods, Lei et al. (2005) detected five SNPs in the chicken IGFBP-2 gene. Li et al. (2006) using PCR-RFLP method detected a C/T SNP in intron 2 of IGFBP-2 gene of chickens.

In this study, the PCR-SSCP approach was used for identification of SNP of the IGFBP-2 gene. The frequency distribution of alleles in four chicken breeds indicated significant differences, which implied that the four chicken breeds demonstrated different polymorphisms at these loci of the IGFBP-2 gene. Results of Chi-square test showed that four chicken breeds were in Hardy-Weinberg equilibrium ( $p>0.05)$.
These results indicated that allele frequency was not changed by selection, mutation, or hybridization factors in the evaluated chicken populations.

The Jinghai Yellow chicken is a new meat minitype breed developed from the Chinese yellow chicken, which is characterized by the adaptability to poor quality feeds and harsh environments. The traditional breeding technique used for Jinghai Yellow chickens has made great improvement in many economically important traits. With the development of molecular genetics, researchers tend to improve the Jinghai Yellow chicken at molecular level. Researchers found that many genes had effects on the body weight of Jinghai Yellow chickens (Tao et al., 2008; Wei et al., 2009; Yu et al., 2010; Hou et al., 2010).

Leng et al. (2009) reported that one SNP (C1996A) of the IGFBP-2 gene was associated with abdominal fat weight and percentage. Li et al. (2006) detected a C/T SNP of the IGFBP-2 gene, which was related to BW, metatarsus length, shank length, femur length, shank weight, femur weight, metatarsus claw weight, and abdominal fat weight of chickens. Lei et al. (2005) studied the association between five SNP of IGFBP-2 gene and growth traits. Results showed that the difference induced by the haplotypes derived from five SNP was more significant than that by the single SNP in the genotype-phenotype association analysis. The haplotypes were associated with BW at hatch and at 21, 28, 42, 49, 56, and $90 \mathrm{~d}$ of age.

In our research, we analyzed IGFBP-2 gene polymorphisms and found two SNPs (C1107G and (1130T) and two insertions/deletions (the inserted/deleted TC after position 552bp and GCCAGGT after 1115bp) in intron 2. The following GLM analysis results showed that chickens with AA genotypes had a significant effect on hatchling weight and body weight at 12 weeks of age compared with the $A B$ genotype $(p<0.05)$. DeKoning et al. (2003) reported that a QTL for carcass weight was mapped between marker brackets MCW0030 and MCW0236 (about 2.3 to $29 \mathrm{Mb}$ ) on GGA7, a region that contains the chicken IGFBP-2 gene (23 to 24 $\mathrm{Mb}$; however, the mechanism by which this gene affect carcass weight still requires further study for confirmation. 


\section{CONCLUSION}

In this study, two SNPs and two insertions/deletions in intron 2 of IGFBP-2 gene were found in four chicken populations (Jinghai Yellow, Youxi, Arbor Acre, and Bian chickens). The identified SNPs influence the function of chicken IGFBP-2 gene and are related with body weight. The findings of the present study not only provide a basis for maker-assisted selection of Jinghai yellow chicken, but also represent a reference for further studies using other chicken breeds.

\section{ACKNOWLEDGEMENTS}

This work was founded by the Heilongjiang postdoctoral Fund (LBH-Z13184), the National Brolier Industrial and Technology System (No. nycytx42-G1-05). The authors gratefully acknowledge the members of the Jinghai Yellow Group Corporation in Jiangsu Province for providing the experiment birds. The authors also thank other co-workers for their help.

\section{REFERENCES}

Bai JY, Zhang Q, Jia XP. Comparison of different foreground and background selection methods in marker marker-assisted introgression. Journal of Genetics and Genomics 2006;33(12):1073-1080.

Cohick WS, Clemmons DR. The insulin-like growth factors. Annual Review of Physiology 1993;55:131-153.

DeKoning DJ, Windsor D, Hocking PM, Burt DW, Law A, Haley CS, et al. Quantitative trait locus detection in commercial broiler lines using candidate regions. Journal of Animal Science 2003;81(5):1158-1165.

Hoeflich A, Wu M, Mohan S, Foll J, Wanke R, Froehlich T, et al. Overexpression of insulin-like growth factor-binding protein-2 in transgenic mice reduces postnatal BW gain. Endocrinology 1999;140(12):5488-5496.

Hou QR, Wang JY, Wang HH, Li Y, Zhang GX, Wei Y. Analysis of polymorphisms in exons of the LYZ gene and effect on growth traits of Jinghai Yellow chicken. International Journal of Poultry Science 2010;9(4):357-362.
Lamont ST, Lakshmanan N, Plotsky Y, Kaiser MG, Kuhn M, Arthur JA, et al. Genetic markers linked to quantitative traits in poultry. Animal Genetics $1996 ; 27(1): 1-8$.

Leng L, Wang S, Li Z, Wang Q, Li H. A polymorphism in the 3'-flanking region of insulin-like growth factor binding protein 2 gene associated with abdominal fat in chickens. Poultry Science 2009;88(5):938-942.

Lei MM, Nie QH, Peng X, Zhang DX, Zhang XQ. Single nucleotide polymorphisms of the chicken insulin-like factor binding protein 2 gene associated with chicken growth and carcass traits. J. Poultry Science 2005;84(8):1911-1918.

Li ZH, Li H, Zhang H, Wang SZ, Wang QG, Wang YX. Identification of a single nucleotide polymorphism of the insulin-like growth factor binding protein 2 gene and its association with growth and body composition traits in the chicken. Journal of Animal Science 2006:84(11):29022906 .

Rajaram S, Baylink DJ, Mohan S. Insulin-like growth factor-binding proteins in serum and other biological fluids: Regulation and functions. Endocrine Review 1997;18(6): 801-831.

Silha JV, Murphy LJ. Insulin-like growth factor binding proteins in development. Advance in Experimental Medicine and Biology 2005:567:55-89.

Shimasaki S, Ling N. Identification and molecular characterization of insulin-like growth factor binding proteins (IGFBP-1, -2, -3, -4, -5 and -6). Progress Growth Factor Research 1991;3(4):43-266.

Schoen TJ, Mazuruk K, Waldbillig RJ, Potts J, Beebe DC, Chader GJ, et al. Cloning and characterization of a chick embryo CDNA and gene for IGF-binding protein-2. Molecular Endocrinology 1995;15(1):49-59.

Tao Y, Li GH, Hu YP, Mekki MD, Chen KW. Genetic effects of MC4R and POU1F1 gene on the growth performance in Jinghai Yellow chicken. Hereditas 2008;30(7):900-906

Wang W, Meng Q, Hu X, Fei J, Feng J, Liu W, et al. Chromosome location and association of haplotypes of insulin-like growth factor binding protein-2 with production performance in swine. Biochemical Genetics 2008;46(7-8):381-391.

Wei Y, Wang JY, Liu DL, Yu YB, Zhang GX. Correlation analysis on single nucleotide polymorphism of the $\mathrm{GH}$ gene and carcass traits in Jinghai Yellow Chicken. China Poultry 2009;31(12):15-18

Yu YB, Liu DL, Wei Y, Zhang GX, Wang JY. Association of single nucleotide polymorphisms in osteopontin exon 6 and parts of intro 6 with growth and reproduction traits in Jinghai Yellow chicken. Journal of Yangzhou University, Agricultural and Life Science Edition 2009;30(2):21-24 
